\title{
Gonçalves, Leandro Pereira Plínio Salgado: um católico integralista entre Portugal e o Brasil (1895-1975)
}

Rodrigo Santos de Oliveira*

Lisboa: Imprensa de Ciências Sociais, 2017.381 p.

O filósofo da ciência Karl Popper (1980) costumava afirmar que o conhecimento científico é, acima de tudo, uma luta contra o marasmo e as supostas verdades preestabelecidas dentro do próprio campo científico. Podemos compreender esse "marasmo" e as "supostas verdades estabelecidas", em parte, como os próprios estudos científicos que marcam época e criam um establishment em determinada área de pesquisa.

Tais obras, mesmo tendo grande importância em seu tempo, acabam tornando-se "dogmas" e, por consequência, "doutrinas" que muitos pesquisadores não ousam romper. Mas, como a ciência é dinâmica e viva, de tempos em tempos surgem estudos que rompem as barreiras do senso comum ou do establishment e apresentam novas visões que oxigenam o saber.

Plínio Salgado: um católico integralista entre Portugal e o Brasil (18951975) do historiador Leandro Pereira Gonçalves é um desses estudos que acrescentam nova luz às pesquisas sobre o integralismo brasileiro.

Se, à primeira vista, o título da obra indica que o autor realiza uma biografia de Plínio Salgado, no entanto não é isso o que se apresenta aos leitores. Embora os estudos sobre o integralismo ainda necessitem de biografias críticas de Plínio Salgado - aqui desconsideramos a biografia feita por Maria Amélia Salgado Loureiro (2001) -, a proposta é inversa, e não menos importante.

No caso, o autor apresenta uma pesquisa original acerca de um período ignorado durante as quase cinco décadas de estudos sobre o integralismo: o exílio de Salgado em Portugal durante os anos de 1939 e 1945. Em outras palavras, é uma obra que está entre as duas grandes "placas tectônicas" dos estudos sobre integralismo - entre a Ação Integralista Brasileira (1932-1937) e o Partido de Representação Popular (1945-1965).

\footnotetext{
* Universidade Federal do Rio Grande (FURG), Instituto de Ciências Humanas e da Informação, Rio Grande, RS. oliv.rod@hotmail.com <https://orcid.org/0000-0003-1829-1347>
} 
Por ser um período pouco estudado - senão negligenciado -, é visto como mera etapa de adaptação de Plínio Salgado entre a vertente fascista, da década de 1930, e a sua autorreformulação, nas décadas de 1940, 1950 e 1960. Nessas leituras superficiais, Plínio Salgado teria apenas se adequado aos "novos tempos".

Aliás, esse é um problema que acompanha uma parcela considerável dos trabalhos e reflexões em Longue Durée sobre Plínio Salgado. O líder integralista é sempre marcado por uma leitura maniqueísta, como se sempre tivesse sido um líder fascista, permanecendo assim ao longo de sua trajetória. Dessa forma, o escritor modernista dos primeiros anos da década de 1920 é visto como o líder integralista da década seguinte, planejando sua escalada ao poder, ao passo que é exatamente ao longo deste segundo período que ele despertou seu pensamento conservador, ultranacionalista e religioso. E, no início da década de 1930, encontrou no fascismo um modelo de pensamento que estava de acordo com sua visão de mundo naquele momento.

Em outras palavras, as discussões sobre a produção modernista nas correntes conservadoras na década de 1920, sua frustrada participação política dentro do Partido Republicano Paulista e a ascensão dos regimes fascistas europeus o influenciaram e criaram a base que o levaria a fundar a Ação Integralista Brasileira (AIB) na década de 1930.

A pesquisa de Leandro Gonçalves nos permite perceber um fenômeno semelhante. Durante o exílio de Salgado em Portugal e com o desenvolvimento da Segunda Guerra Mundial, novas influências foram surgindo: o modelo fascista entra em colapso, ao mesmo tempo que os regimes autoritários ibéricos - Portugal e Espanha, embora com modelos distintos, mas que "flertaram" com o fascismo na década de 1930 - se afastam e conseguem se adaptar à realidade que já se delineava a partir do final de 1942 (no caso, a derrota do Eixo). Isto é, uma nova polarização global que já se podia vislumbrar no horizonte (Estados Unidos da América e União Soviética), a partir do final de 1944.

Logicamente, esses acontecimentos tiveram relevância no pensamento de Plínio Salgado, assim como a intervenção política e literária que desenvolveu durante o exílio, o ponto central de Gonçalves.

A obra aqui resenhada divide-se em cinco capítulos.

No primeiro - "Plínio Salgado conhece Portugal: formação e desenvolvimento" -, o autor aborda suas origens familiares e sociais, assim como a gestação intelectual do pensamento "pliniano". Aqui merece destaque o resgate de Salgado, no período modernista, como mentor e líder máximo da AIB. Cabe destacar a funcionalidade do capítulo que contextualiza o período. Ou seja, serve tanto para o leitor leigo sobre Plínio Salgado e sobre o integralismo, como 
para o pesquisador que já tem bases sobre o tema, apresentando dados relevantes e interpretações concisas e coesas.

No segundo capítulo - "A 'revolução legal' e o exílio em Portugal” -, discorre sobre a prisão e o exílio de Plínio Salgado. Resgata o conturbado contexto que levou ao golpe do Estado Novo e à participação integralista nesse processo. $\mathrm{O}$ autor aprofunda a questão da instauração da ditadura de Getúlio Vargas e a paulatina perda de espaço dos integralistas nessa nova realidade, até chegar à fracassada "empreitada" de deposição de Vargas na Intentona Integralista de 1938, que culminaria na prisão e exílio de Plínio Salgado, no ano seguinte. Revela os pormenores da negociação que garantiu a Salgado a possibilidade de exílio ao invés de amargurar a prisão política nas prisões estado-novistas. Nessa mesma parte, dá-nos uma visão geral do período de exílio e das questões políticas envolvidas nessa condição de Plínio Salgado.

O terceiro capítulo - "Plínio Salgado em Portugal: necessidade de um novo discurso" - tem como eixo central a "reconversão" do pensamento "pliniano": de Chefe Nacional de um movimento enquadrado como fascista para um pensador católico conservador. Nessa parte, o destaque fica para a obra Vida de Jesus (1942), que serviu como instrumento político para a reestruturação de seu pensamento e uma nova inserção política nos meios culturais do Estado Novo português, sob Oliveira Salazar. Como aponta Leandro Gonçalves, essa obra foi o ponto de inflexão que permitiu a Salgado passar de ex-líder da AIB à condição de pensador católico luso-brasileiro. E, com essa nova "roupagem", vai se inserir tanto na sociedade lusitana como posteriormente vai remodelar o integralismo (de fascista no pré-guerra para conservador cristão anticomunista no pós-guerra).

No quarto capítulo - "Conferencista e escritor luso-brasileiro" - o autor explora a práxis política de Plínio Salgado no exílio, mostrando suas estratégias de atuação como intelectual conservador - ato que "serviu como uma luva" no contexto salazarista da primeira metade da década de 1940. Aqui merece destaque a questão religiosa, que podia ser vista na sua produção nas décadas anteriores - a qual, nesse momento, passa a ter papel mais incisivo -, assim como a difusão de um pensamento "nacionalista cristão" e a reconfiguração do discurso em defesa do espiritualismo, mas adaptado à defesa da democracia. Aqui, Gonçalves nos mostra a reestruturação do pensamento "pliniano" no contexto do final da Segunda Guerra Mundial. O discurso de Plínio Salgado tem uma virada de 180 graus: da defesa de uma forma autoritária (ou totalitária) de "Estado Integral" para a defesa da democracia. 
No quinto e último capítulo - "Retorno ao Brasil: um 'Plínio Salazar'?" - apresenta-se ao leitor o desfecho do processo histórico da obra (o exílio de Plínio Salgado) com a reestruturação do pensamento do "Chefe Integralista" no Pós-Guerra. Inicialmente, o autor reflete sobre as influências do contexto do Estado Novo salazarista (a defesa de uma "democracia-cristã"); sobre o retorno de Salgado ao Brasil, com essa nova "visão luso-brasileira" de mundo, e como isso esteve presente na ação do Partido de Representação Popular, e aponta a defesa do colonialismo lusitano. Por fim, dá um "salto no tempo", mostrando brevemente a intervenção "salgadiana" e "perrepista" no Golpe de 1964 e a intervenção na Aliança Renovadora Nacional (Arana) - partido que era o sustentáculo político do governo ditatorial.

A pesquisa supre uma grande lacuna na historiografia sobre o integralismo brasileiro - o período de exílio do Chefe Nacional - e permite-nos visualizar como ocorreu a reformulação ou reestruturação do pensamento de Plínio Salgado entre os anos de 1939 e 1945.

Como todo movimento que surge no "roldão" do fascismo das décadas de 1920 e 1930, o integralismo brasileiro esteve completamente marcado pela imagem do líder. O pensamento de Plínio Salgado foi a base central do integralismo. Não há como dissociar ambos. Ao mesmo tempo, essa pesquisa nos permite uma melhor compreensão da intervenção de Plínio Salgado, não de uma maneira maniqueísta do indivíduo fascista, que em toda a sua trajetória manteve um pensamento único, mas como um indivíduo marcado pelo seu tempo de vida e pelas mudanças políticas, econômicas, culturais e sociais que foram ocorrendo ao longo dos anos.

Ao leitor, fica o convite à leitura de uma obra que se torna obrigatória para aqueles que se dedicam ou pretendem se dedicar ao estudo do integralismo brasileiro, ou por aqueles que se interessam por temas políticos de nossa história recente.

\section{REFERENCIAS}

LOUREIRO, Maria Amélia Salgado. Plínio Salgado, meu pai. São Paulo: GRD, 2001. POPPER, Karl. Conjecturas e refutações. Brasília: Ed. UnB, 1980.

Resenha recebida em 28 de janeiro de 2020. Aprovada em 22 de abril de 2020.

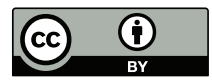

